\title{
The Correlation between Lawrence Modernist Poetry and Impressionism Painting
}

\author{
Ding Liming \\ Jiangxi Science \& Technology Normal University 330038 \\ yonghuadeng@163.com
}

\begin{abstract}
David Herbert Lawrence (1885-1930) was an outstanding modernism novelist and poet in the 20th century, who was known as "one of the greatest figures in English literature history. It is known that Lawrence's literary career started with poetic songs, and the earliest two poems "Hydrangea" and "Lychnis” began in the spring of 1905, after Lawrence won scholarships. Actually for early Lawrence "writing poetry itself does not represent a commitment to anything, and it is a literary youth who writes naturally in the spare time, which you can take the things themselves happy." (John Watson 43). In fact, Lawrence seemed less interested in painting at the beginning. Since the summer of 1902, Lawrence regularly visited a Chambers in Hargreaves' manor and learned art, made replica of oil paintings with a teen girl Jessy who was good at writing poems and painting. Lawrence modernist poetry and impressionism painting constructed the witness of Lawrence inner thoughts naturally revealed. In view of this, if we examine a single Lawrence's poetry or painting, we cannot fully and accurately explore the essence of Lawrence literature and art. Only literature research paradigm of both poetry and painting is the best choice. Lawrence's poetry and painting are correlated and mutual. Because of painting, Lawrence's poetry interpretation is more vivid, while literati paintings of Lawrence are of great meaning because of external display.
\end{abstract}

\section{Lawrence painting in poetry}

Lawrence poetry can be broadly divided into three stages. Early works (1904-1919) are Love Poems), New Poems and Look! We Have Come Through, which presented to the readers poetry writing theme with Lawrence early sweetness and happiness of love; Medium-term poetry (1920-1927) gave priority to returning to nature and paying attention to all living beings, and the representative work of his poetry creation is Birds, Beasts And Flowers in Italy. In the later period poetry (1928-1930), the poet thought about real life in a rational perspective, especially deep reflections of the good and evil in urban civilization. Poems Pansies, Nettles and More Pansies and Last Poems are models of Lawrence late poetry. Specifically, Lawrence's poems are influenced by Ezra pound greatly, which shows the marks of painting art and later impressionism creation idea: image juxtaposition, visual feeling is strong. British novelist Keith Alldritt, (1935 - ), once spoke highly of Lawrence's writing of poems in Italy as a model of visual art. (Jillian de Vries - Mason, 85) Lawrence's poetry characteristics turn from the early insightfulness and passion to highlight the physical life, and it is very close to Cezanne's impressionist painting style: boldly use pure light and color to build a psychedelic feeling. As Cezanne himself put it, "painting should only emphasize the form, the existence of the material itself and the material." (Same as above, 89) Based on the above analysis, the author thought that Lawrence poetry containing thick painting art is not unfounded.

First, European and American modernist poetry movement pioneer Ezra Pound (1885 -) founded western free verse school based on his deeply cultural diversity and the influence of various schools of art, especially greatly influenced by after impressionism painting represented by Van Gogh and Gauguin. Then in 1909, he recognized British modernism literature theorist and poet Thomas Ernest Hulme (1883-1917) and on the basis of Hume poetics, he created the image of the new poetry. Involved in the Pound image movement in London, Lawrence, but he did not totally agree with Pound imagism three principles. In fact, Italian poet and dramatist Mali's creation of future socialist literary poetry writing style had profound effect on middle Lawrence. In 1909, Filippo Tommaso Marinetti, (1876 1944) published The Declaration of Futurism in France "Le Figaro", and the following year he published The Declaration of Futurism Literature, which clarified the genre' $s$ 
theory and the principle of literary creation. Specifically, it showed distinct characteristics from the futurist poetry in the field of poetry and traditional poetry. It did not value the things' logical relationship on the time, and its logical relationship was based on the identity similar to contrast; it also differs from imagistic poems, and it pursues the mutual existence and mutual performance of both object and significance. Lawrence pursued comprehensive innovation of the contents and forms of poetry, including adhering to "free verse" late poetry creation style, highlighted the role of perceptual phenomenon, catharsis and hidden subjective feeling, powerful usage of effective and real feelings directly to express instant formation of hot emotions and calm thinking. (Li Ke, 180-184) Affected by this, Lawrence overturned grammar in poetry creation with bold innovation of poetry language, made the artificially cut connection between the words and formed a weak connection between sentences. His style was like impressionist paintings conveying only attention to picture material and performance, focused on form and substance, and ignored the inner links between the materials. (D. H. Lawrence, 574).Although not fully agreed to Pound Imagism three principles, there are large amounts of image rendering techniques in clearly echoes with Pond poetry' s Chinese painting style in Lawrence poetry. Pound imagery poetry "In the subway station", "faces in the crowd", "dark damp branches petals "are similar with Li Bai's "Palace play word", Clever arrangement of various images in verse, as well as conventional literary technique and processing method are highly consistent. Lawrence poetry "One white flower", "the moon has a petite, a lonely jasmine, she is alone, hanging on my window, nestled in the winter house "(Wu Di, 63 ) is clearly a Pound imagery version poem. Their common characteristic is loss of conjunctions in traditional poetry, poetry images are seemingly unrelated and independent, but have actually inherent connection between each other, and for readers with rich imagination, poetry is an elegantly beautiful myriad's painting. No wonder the father of British literary criticism, Philip Sidney (1554-1586) in "Apology" has such opinions on the relationship between poetry and painting. He thought, the poet's poetry has two stages. The first phase of the poet is to abstract concept feelings from human senses of the outside world; the second phase, the poet transforms "abstract concept" into "picture", the poet again through language to imitate the "picture", finally create "sound painting". Sidney' s new form of "sound painting" is what he is speaking. This suggests that the poetry and painting are sisters' art, which have the same effect on the reproduction of natural beauty. (He Weiwen, 193-194) Lawrence wrote his feelings in his essays "Phoenix"(II) that "once instinct and intuition are into the eye, painting can be produced immediately." (D. H. Lawrence, 603) Lawrence's poetry creation was with the aid of instinct and intuition feelings. He created nearly thousands of poets in his lifetime, which injected fresh blood to English modernist.

\section{Lawrence's poetry in painting}

In Lawrence prose Introduction to These Paintings, he wrote about the beauty of painting and exquisite technology of painter Paul Cezanne (1839-1839). Cezanne’ s fan Roger Fry (1866-1934) had a special liking to impressionist paintings of Cezanne also. Fry studied museum in his early years, and belonged to the identification of Europe's top art master, later became a post-impressionist painting movement of naming and main interpreter. As a famous British artist and aesthete, in his "Cezanne: A Study of His Development" , wrote to interpret his own unique artistic aesthetics. And his work "Vision and Design "(1920) publish was apparently under Cezanne's artistic achievements and influence. Cezanne was a representative figure of late European impressionist painting, the same as poet Lawrence, Cezanne has been looking for truth of life in his works, namely the real painting. And he gradually realized that the source of his work must be nature, his life, things of the world, rather than the old stories and myths of ancient Greece. He wanted painting come out of the source of new real things. At the same time, Lawrence artistic insight and motorcycling in his late life bring out the best in each other, his poetry paid attention to build a metaphysical life art atmosphere, and exaggerate the effect of visual art of poetry, and the matching of the same name paintings is more intuitive. We can say that Lawrence qualification of 
poetry and painting talent in him has mutual penetration and mutual complement, that he is not only a poet and painter, but a special literary generalist.In artistic style, Cezanne worshiped romantic Delacroix, realistic Courbet, as well as impressionist Monet. Combining with the characteristics of their art form belongs, Cezanne's special creativity formed. In order to emphasize the texture of images, he adopted realist Courbet paint palette knife method, and assisted in the cylinder, sphere and a cone to depict the object painting, in the perspective of relationship between object, not only that he had put an object or a plane of each face toward the center of the screen, creating mass paintings image, stereo feeling, and stability, finally reached the overall image to simplify and geometric effect. In a word, he is not for life, but life for painting, even not for others, and completely for his painting. Because Cezanne in art was not appreciated, he was a lonely explorer, but his will was tenacious, solitary monarch, 20 years after his death, he won the reputation in the industry, and become the painting superstar, who in turn is known as the father of modern art. Lawrence began painting as a teen, but he really obsessed with painting in 1926 . When he was 40 years old, he came to a sudden insight in painting. In The Statement of The Painting (1929) Lawrence said: "Painting gives me the happiness unable to do in big words. Words bring me deep happiness, which is unconscious. And it gives me strong and conscious joy." The phenomenon of the art "blowout" appeared in last few years of Lawrence. An important reason is that he had a hard time, he saw a reflection relationship between world, life and art form to increase the height of art, in the form of literature and painting, two present physical vitality of artistic beauty, the achievement in artistic life is a strong magnetic field completing harmony between art and life. This is an important way and means of knowing binary relation of Lawrence poetry and painting. A series of paintings and watercolors Lawrence's painting "Resurrection", "Home of the saints", "Sun", "Found of Moses", and "Boccaccio's story" are a total of 25. They are works that Lawrence worked for nearly three years with agony but still insisted on writing life. When he was painting the impulse than writing impulse, all appearing full-bodied life vigor, picture color is colorful, mostly are exaggeration and deformation characters, the picture on the whole builds a strong visual impact and tension. This echoes his poetry creation. In a large number of middle and later poems, Lawrence showed strong, natural and vibrant vitality of the universe. Lawrence broke the traditional poetry rhyme in the poem so as to return things to true colors.

To be specific, the poem "River rose", "Magnificent yellow rose", "Meet in a mountainous area" and "Spring morning" and so on are all powerful examples for the poet who is influenced by impressionist painter Cezanne Lawrence. In Birds, Beasts, and Flowers, Lawrence paid closer attention to nature. "FIG", "Apricot flowers", "Hummingbird" and "Turtle" and so on, poetry language space and language visual conveying degrees are well presented in front of the readers. Lawrence was happy with the aid of Cezanne's painting strong intuition and realistic style of painting in poetry creation and experience; because he thought that "we live a too rational era. We know too much, but perceive too little." (Ditto, 202) As a result, he was opposed to using traditional strict laws of metrical poetry, as he tried to refute painter to paint with modern art theory. Painters and poets, in his opinion, art belongings are different, but if the painter is todraw real works of art, if you want to write a moving poetry, it must be "close your theory eyes, and use your instinct and intuition to painting and creation." (Ditto, 203) Based on this, Lawrence's poetry "Mosquito knows" and "waves" are the masterpieces. In "Mosquito knows" , poet did not apply too much hypocrisy, but use simple and direct words to expose the nature of mosquitoes: small body eats beast in the blood. "Waves" is more intuitive, visual perception and imagination together forms a picture of real and wild: wave shocking rock is personified as angry people; the wave' $s$ bubbles become white flowers, and there is an effect of hearing: hissed hair ring. The technique expression of poetry clearly is the influence of Cezanne's painting marks and evidence, which is his consistent style and manner. In his prose "Art and morality", he repeated image sense of reality:Take a snapshot of your sweet girl in flowers, and she smiled gently to give a cabbage leaf to red cow and calf. This is very beautiful and true. In photos, your lover is very complete, and is enjoying an absolute objective truth. Perfect complete environment made her look more perfect, and she really became "a picture". (Ditto, 237) 


\section{Conclusion}

Lawrence is one of the representatives of modernist school poetry. There is no doubt that his poetry is full of innovation and change. Due to the influence of impressionism painting in poetry creation, it is understandable and imaginative that it is filled with images of texture and aesthetic feelings. Given that Lawrence filed his late life, on the other hand, with brush to create the art of painting and poetry creation at the same time, his paintings and poetry homologous phenomenon is normal. So, Lawrence modernist school poetry and late impressionism painting construction correlation is based on the fact of reasonable inference but unfounded .

\section{References}

[1] D. H. Lawrence, Phoenix II, Viking Press, 1968, p. 603.

[2] D. H. Lawrence, the Introduction to These Paintings, Phoenix, 1929, p. 574

[3] Jillian de Vries - Mason, the Perception in the Poetry of D. H. Lawrence, Peter Lang Ltd., 1982, p. 85

[4] He Weiwen. "On Sidney's < apology > poet's divine", "[J], Foreign Literature Review, 2014 (3) : 193-194.

[5] Li Ke. The confusion and decay in convergence of old and new culture - the fate of future socialist literary [J], Journal of Lanzhou University, 2000 (28): 180-184.

[6] John Watson. "Lawrence: an outsider's life" [M]. Shi Lei. Shanghai Bookstore Publishing House,2012, page 43.

[7] Wu Di. "Ship: selected poems of Lawrence" [D]. Shanghai People's Publishing House, 2012, p. 63. 